A N N A L E S

UNIVER S T ATIS M A R A E C URIE-SKŁODOW K A

LUBLIN - POLONIA

VOL. XXXI, 1

SECTIO J

2018

Uniwersytet Marii Curie-Skłodowskiej w Lublinie. Wydział Pedagogiki i Psychologii

\title{
URSZULA LEWARTOWICZ
}

urszula.lewartowicz@umcs.lublin.pl

\section{Animacja społeczno-kulturalna jako metoda przeciwdziałania wykluczeniu z kultury}

Social and Cultural Animation as a Way of Counteracting Exclusion from the Culture

\section{STRESZCZENIE}

Celem artykułu jest scharakteryzowanie animacji społeczno-kulturalnej jako metody przeciwdziałania wykluczeniu z kultury. Punktem wyjścia proponowanych rozważań jest szerokie rozumienie kultury - nie tylko jako wartości autotelicznej, ale przede wszystkim jako narzędzia społecznej partycypacji i aktywizacji oraz jednego z fundamentów budowania kapitału społecznego. W opracowaniu przedstawiono kluczowe założenia animacji w perspektywie inkluzji społeczno-kulturalnej. Scharakteryzowano najważniejsze modele i paradygmaty animacji, akcentujące wątki związane z problematyką wykluczenia społeczno-kulturalnego. Zaprezentowano również animacyjny program „Dzielnice Kultury”, stanowiący praktyczną egzemplifikację omawianych zagadnień. Program od 2013 r. z powodzeniem jest realizowany przez miasto Lublin. Jego celem jest usuwanie przestrzennych, organizacyjnych i finansowych barier w dostępie do kultury, a tym samym integracja i aktywizacja społeczno-kulturalna mieszkańcow.

Slowa kluczowe: animacja społeczno-kulturalna; wykluczenie z kultury; wykluczenie społeczne; inkluzja społeczno-kulturalna

\section{WPROWADZENIE}

Niniejsze opracowanie ma na celu przybliżenie problematyki animacji społeczno-kulturalnej w kontekście procesów wykluczenia społecznego i kulturalnego. Artykuł prezentuje kluczowe idee i założenia animacji, czyniące z niej efektywną metodę przeciwdziałania wykluczeniu z kultury, oraz przybliża najważniejsze tradycje i dokonania w tym obszarze, ukazując również ich współczesną egzemplifikację w postaci konkretnego projektu animacyjnego. 
Idea animacji społeczno-kulturalnej od blisko 30 lat gości w polskiej teorii i praktyce pedagogicznej. W tym czasie stała się powszechną metodą nie tylko działalności kulturalnej, ale i społecznej i edukacyjnej, wkraczając także w inne obszary i dziedziny życia, takie jak ekonomia, sport, rozrywka i rekreacja. Tym samym stale ujawniają się nowe konteksty animacji. Należy jednak podkreślić, iż kluczowe dla niej idee i założenia wciąż pozostają niezmienne. Jedną z nich jest kategoria inkluzji społecznej.

Inkluzywny potencjał animacji jest głoszony w zasadzie od początku jej istnienia, co można odnotować zarówno w odniesieniu do koncepcji zagranicznych, jak i rodzimych wykładni. W ostatnich latach inkluzywne intencje animacji wybrzmiewają jednak szczególnie dosadnie, co z jednej strony jest zdeterminowane popularyzacją animacji jako metody działań społeczno-edukacyjnych, z drugiej zaś coraz wyraźniejszym artykułowaniem związków pomiędzy kategorią inkluzji społecznej a szeroko rozumianą kulturą. Już w 1994 r. Bell pisał, że kultura przejmuje inicjatywę promowania zmian (Bell 1994, s. 25). Rolę kultury w procesach inkluzji społecznej uwypukla przyjęta w 2010 r. przez Komisję Europejską strategia „Kultura 2020”. Jednym z jej głównych celów jest wzrost gospodarczy (inclusive growth), sprzyjający całemu społeczeństwu i przeciwdziałający wykluczeniu społecznemu. Sektor kultury oraz przemysły kreatywne wzmacniają takie obszary, jak zatrudnienie, innowacyjność, spójność społeczna, przyczyniając się tym samym w znacznym stopniu do wzrostu gospodarczego (Rokicka 2013, s. 8).

Kłosowski mówi wręcz o kulturze inkluzywnej, rozumianej jako kultura otwarta oraz zachęcająca do uczestnictwa, stwarzająca możliwość spotkań i wymiany doświadczeń. Nie ma w niej miejsca na tradycyjne podziały na odbiorców i twórców. Czołową wartością dla kultury inkluzyjnej jest codzienność. Dzięki temu respektowane są jednostkowe potrzeby i preferencje kulturowe. Takie rozumienie kultury jest przeciwstawne wobec modelu kultury ekskluzywnej, zasadzającej się na jednokierunkowych przekazach i zamkniętej w przestrzeniach zinstytucjonalizowanych, ujmowanych nierzadko jako świątynie sztuki (Kłosowski 2011a, s. 13-14).

Wzrost zainteresowania inkluzywnymi kontekstami kultury ujawnia jednocześnie braki i zaniedbania w tym obszarze, szczególnie w odniesieniu do tzw. drugiego układu kultury, czyli kultury zinstytucjonalizowanej. Kwestie związane z tą problematyką stały się przedmiotem zainteresowania m.in. autorów raportu badawczego Oblicza ekskluzji. Praktyka działania instytucji kultury a przełamywanie barier (Rokicka, Kruczkowska [red.] 2013). Raport pokazuje, że „kultura jest jednym z wymiarów wykluczenia i jednocześnie przestrzenią reprodukcji dyskursów legitymizujących formy wykluczenia »na życzenie«" (Bendyk 2013, s. 14).

\section{USTALENIA TERMINOLOGICZNE}

Wykluczenie społeczne jako zjawisko socjologiczne stało się przedmiotem dociekań naukowych w latach 60. ubiegłego stulecia. Tym samym znacznie został 
poszerzony zakres pojęcia, wcześniej skoncentrowany przede wszystkim wokół kontekstów gospodarczych i politycznych. W perspektywie socjologicznej wykluczenie społeczne ,odnosi się do sytuacji, w której jednostki zostają pozbawione pełnego uczestnictwa w społeczeństwie" (Giddens 2004, s. 45).

$\mathrm{Na}$ gruncie teoretycznym dostępny jest szereg definicji wykluczenia społecznego, akcentujących jego rozmaite konteksty. Próbę ich uporządkowania podjął Szarfenberg, wyróżniając cztery podstawowe nurty. Pierwszy z nich koncentruje się wokół problematyki uczestnictwa, definiując wykluczenie społeczne jako niezdolność do partycypacji w ważnych obszarach życia: politycznym, gospodarczym, kulturowym. Drugi nurt skupia się przede wszystkim wokół aspektów związanych z prawami społecznymi obywateli w obszarze socjalno-bytowym. Nurt trzeci rozpatruje wykluczenie społeczne głównie w kontekście dostępności koniecznych zasobów: społecznych, gospodarczych, instytucjonalnych. Ostatnią grupę stanowią definicje łączące zjawisko wykluczenia społecznego z deprywacją - zarówno w znaczeniu obiektywnym (ograniczenia materialne), jak i subiektywnym (poczucie niższości) (Szarfenberg 2010, s. 132-133). Bez względu na to, w którym ze wskazanych nurtów będziemy lokować konkretną definicję wykluczenia społecznego, można wskazać kilka uniwersalnych cech charakteryzujących omawiane zjawisko. Wymienia się wśród nich m.in.: zmniejszoną ilość praw przy zwiększonej ilości obowiązków; pozbawienie władzy oraz dostępu do podejmowania decyzji; zmniejszoną ilość możliwości wyboru przy zwiększonej ilości ograniczeń; niewielkie możliwości zawodowe, edukacyjne, rekreacyjne itp.; niższą pozycję ekonomiczną; dyskryminację prawną; zwiększony stopień narażenia na skutki społecznych kryzysów i nacisków; napiętnowanie (naznaczenie) społeczne; dyskryminację prawną; inne praktyki dyskryminujące (Mahler 1993, s. 193).

Odpowiedzią na problemy związane ze zjawiskiem wykluczenia są różnorodne procesy i działania, które określa się najogólniej mianem inkluzji społecznej. Zdaniem Kłosowskiego inkluzję społeczną (włączenie społeczne) należy definiować jako posiadanie realnej możliwości partycypacji w życiu społecznym, a więc przebywania między ludźmi, zawierania przyjaźni i znajomości, zdobywania szacunku, podejmowania pracy oraz utrzymywania się, wreszcie pełnienia istotnych ról społecznych (Kłosowski 2011b, s. 82).

Przyjmując rozróżnienie Szarfenberga, problematykę związaną z wykluczeniem kulturalnym należałoby lokować w ramach pierwszego $\mathrm{z}$ wyodrębnionych nurtów, czyli w modelu partycypacyjnym. Za Nalaskowskim można przyjąć, że wykluczenie społeczne oznacza brak bądź ograniczenie partycypacji jednostek lub grup społecznych w istotnych obszarach życia społecznego, związanych nie tylko z uczestnictwem w relacjach rodzinnych, sąsiedzkich czy koleżeńskich, ale również w wydarzeniach znajdujących się w ofercie instytucji kulturalnych czy oświatowych (Nalaskowski 2007, s. 25). Można tym samym mówić o wykluczeniu z uczestnictwa w kulturze. Korzystając z definicji wykluczenia społecznego 
sformułowanej przez Friske (1999), zjawisko wykluczenia z uczestnictwa w kulturze należy utożsamiać z sytuacją jednostki bądź grupy społecznej, rodzącą ograniczone możliwości czy uprawnienia (przysługujące wszystkim członkom społeczeństwa) do partycypacji kulturalnej.

Problematyka wykluczenia kulturalnego w literaturze przedmiotu jest podejmowana dość rzadko. Nieliczne opracowania naukowe poświęcone temu zagadnieniu ogniskują się przede wszystkim wokół instytucjonalnych form uczestnictwa w kulturze. W tym kontekście główną osią zainteresowania badaczy stają się kwestie związane z dostępnością kultury. Kukołowicz wyróżnia trzy jej wymiary: geograficzny, społeczny i indywidualny. Pierwszy dotyczy tych obszarów dostępności kultury, które są związane z miejscem zamieszkania, w związku z czym osoby zamieszkujące tę samą okolicę posiadają podobny dostęp do kultury. Wymiar społeczny jest związany przede wszystkim z cechami, które są wspólne dla gospodarstwa domowego (np. poziom zarobków). Z kolei wymiar indywidualny obejmuje cechy typowe dla konkretnej osoby, m.in. wiek i indywidualne kompetencje. W tym obszarze mieszczą się również niepełnosprawności, zakładając, iż są one czynnikiem utrudniającym dostęp do kultury (Kukołowicz 2016, s. 104).

Kwestie dostępności kultury są związane bezpośrednio z zagadnieniem barier utrudniających kontakty z kulturą. Szwedzkie badania zogniskowane wokół tej problematyki pokazują, że do najważniejszych czynników utrudniających uczestnictwo w kulturze można zaliczyć: bariery czasowe, przestrzenne (związane z odległością i siecią komunikacyjną), socjologiczne (brak kontaktów, anonimowość, izolacja), ekonomiczne, fizjologiczne (ułomność, choroba, zmęczenie), psychologiczne (alienacja, brak wiary w siebie). Znamienne jest to, że - jak pokazały badania - likwidacja wskazanych barier nie gwarantuje intensyfikacji kontaktów z kulturą i wzrostu aktywności społeczno-kulturalnej. Autentyczne potrzeby kulturalne, będące kluczowym warunkiem uczestnictwa w kulturze, są rozwijane dopiero w wyniku działań edukacyjnych i animacyjnych (Grad, Kaczmarek 2005, s. 121). Podobne wnioski odnajdujemy w nielicznych opracowaniach powstałych na gruncie polskim (por. Kukołowicz 2016).

INKLUZYWNE PRZESŁANKI ANIMACJI SPOŁECZNO-KULTURALNEJ TEORIA I PRAKTYKA

Animacja społeczno-kulturalna zrodziła się we Francji. Pierwsze wzmianki na jej temat odnajdujemy we francuskim piśmiennictwie naukowym z lat 40 . ubiegłego stulecia. Rozwój koncepcji nastąpił w latach 60., niewiele później zaistniała ona w polskich opracowaniach naukowych. Na przełomie lat 80. i 90. zaczęła się kształtować rodzima wykładnia animacji. Główne cele animacji społeczno-kulturalnej to: wyzwalanie potencjałów twórczych jednostek, grup i społeczności lokalnych; rozbudzanie aktywności i kreatywności; wzmacnianie komunikacji 
oraz integracji; wspomaganie autentycznych potrzeb uczestnictwa w życiu społeczno-kulturalnym. Animacja pełni tym samym istotne funkcje, które można rozpatrywać zarówno w perspektywie osobowej, jak i społecznej. W grupie najważniejszych funkcji animacji społeczno-kulturalnej wskazuje się następujące: komunikacyjna, partycypacyjna, edukacyjna, informacyjna, adaptacyjna. Humanistyczne oraz demokratyczne wartości, stanowiące podstawę animacyjnej teorii i praktyki, determinują możliwość interpretowania jej nie tylko jako efektywnej metody edukacji kulturalnej czy sposobu aktywizowania lokalnych społeczności, ale również jako metody zapobiegania nierównościom społecznym oraz przeciwdziałania zjawiskom wykluczenia i marginalizacji. Inkluzywny potencjał animacji społeczno-kulturalnej podkreśla wielu teoretyków i badaczy. Idzikowski np. wskazuje, że koncepcja animacji społeczno-kulturalnej jest ukierunkowana na „humanistyczny paradygmat podciągania dołów, włączania wykluczonych w nurt życia społecznego, ukierunkowanie na budzenie sprawczej woli i chęci działania" (Idzikowski 2013, s. 46).

Źródła inkluzywnego sposobu definiowania animacji społeczno-kulturalnej sięgają początków formowania się koncepcji animacji. W sposób najbardziej wyraźny zostały one wyartykułowane w modelu włoskim, którego rozkwit datuje się na lata 70. ubiegłego stulecia. Należy tu wspomnieć przede wszystkim o działaniach animacyjnych realizowanych $\mathrm{w}$ tym czasie $\mathrm{w}$ dzielnicach położonych na przedmieściach włoskich miast, które miały służyć właśnie zapobieganiu wykluczeniu z kultury. Inicjatorem tych działań był Scabia - aktor oraz reżyser turyńskiego teatru Teatro Stabile. Był on twórcą laboratoriów teatralnych, powstających w jednej z najbardziej ubogich spośród nowo powstałych dzielnic Turynu, wymownie nazywanej przez mieszkańców „sypialnią” bądź „więzieniem”. Animacja stała się w tym wypadku metodą przeciwdziałania wykluczeniu kulturalnemu, zaś formy teatralne, którymi się posługiwano, stworzyły szansę zobrazowania i przedstawienia codziennych problemów mieszkańców dzielnicy (Lewicki 1993, s. 133).

Włoskie tradycje animacji zapoczątkowały nurt myślenia o niej jako o metodzie przeciwdziałania marginalizacji i wykluczeniu z kultury. W najbardziej ogólnym rozumieniu inkluzja społeczno-kulturalna w perspektywie animacyjnej jest realizowana przez wyzwalanie oraz rozwijanie aktywnej i twórczej partycypacji kulturalnej, a także przez integrację jednostek i grup społecznych we wspólnotowych działaniach o charakterze kulturotwórczym (Kubinowski 2013, s. 20). W ten sposób animacja staje się „lekarstwem” nie tylko na kwestie stricte kulturalne, ale i na wiele kontekstów życia społecznego, dotyczy bowiem rozmaitych sfer życia - aktywności obywatelskiej i politycznej, pracy, czasu wolnego, życia rodzinnego, z którymi kluczowa dla animacji kategoria kultury pozostaje w ścisłym związku (Grad, Kaczmarek 2005, s. 123).

Bardziej szczegółowe charakterystyki animacji ujmowanej w perspektywie inkluzji społeczno-kulturalnej można odnaleźć, analizując jej konkretne kon- 
cepcje i modele. Wątki inkluzji w sposób najbardziej wyraźny uwidaczniają się w koncepcji wspólnotowej, emancypacyjnej oraz partycypacyjnej. Koncepcja wspólnotowa uwypukla rolę animacji w zapobieganiu i przeciwdziałaniu zjawiskom społecznej izolacji oraz włączaniu do grup społecznych tzw. outsiderów. Model emancypacyjny łączy animację głównie z działaniami mającymi na celu walkę z dyskryminacją i marginalizacją różnorodnych grup społecznych, dążąc tym samym do pokonywania kulturowych, politycznych i społecznych barier. Z kolei koncepcja partycypacyjna akcentuje konieczność podejmowania inicjatyw animacyjnych w środowiskach potrzebujących społecznej przestrzeni, stanowiącej pole współdziałania i współpracy (Mendel 2004, s. 16-17).

Inkluzywne intencje animacji społeczno-kulturalnej są w ostatnim czasie na tyle nośne, że stały się kluczową przesłanką jednego z trzech współczesnych paradygmatów animacji. Kubinowski określił ów paradygmat mianem animacji zmiany prohumanistycznej. Jego zasadniczym celem jest poszukiwanie obszarów defaworyzacji, marginalizacji i wykluczenia, a następnie realizacja działań, które miałyby tym zjawiskom zapobiegać. Model ten opiera się przede wszystkim na wartościach prohumanistycznych i prodemokratycznych, które są warunkiem koniecznym konstruktywnej zmiany - tak osobowej, jak i społecznej. Kultura pełni w tym wypadku rolę indywidualnej i wspólnotowej przestrzeni w walce „o lepszy świat dla wszystkich ludzi" (Kubinowski 2013, s. 18).

Tak silną pozycję we współczesnej teorii animacyjnej wątki inkluzywne zawdzięczają zwłaszcza konkretnym projektom i działaniom, coraz chętniej i z coraz większą efektywnością podejmowanym dziś przez animatorów kultury. Animacja jest bowiem dyscypliną głównie praktyczną i to właśnie w praktyce w sposób szczególny uwidaczniają się jej aktualne tendencje. Egzemplifikację charakteryzowanego w niniejszym opracowaniu modelu animacji może stanowić miejski program „Dzielnice Kultury”, od 5 lat z powodzeniem realizowany w lubelskich dzielnicach. W swoich założeniach bardzo wyraźnie nawiązuje on do włoskich tradycji animacji, będąc czytelnym przykładem strategii ukierunkowanej na przywoływany już „humanistyczny paradygmat podciągania dołów”.

Lubelski program „Dzielnice Kultury” został zainicjowany w 2013 r. na fali kulturalnego ożywienia, jakie towarzyszyło staraniom miasta o tytuł Europejskiej Stolicy Kultury 2016. Program powstał w odpowiedzi na zjawisko silnego scentralizowania infrastruktury kulturalnej, będące źródłem dysproporcji w dostępności kultury, ujawniających się szczególnie w przypadku mieszkańców tzw. dzielnic peryferyjnych. Centralną kategorią programu stała się właśnie kultura inkluzyjna, rozumiana jako przestrzeń tworzenia i dzielenia się wartościami, aktywizująca każdego człowieka i stanowiąca warunek rozwoju społeczeństwa obywatelskiego. Przyjęto, iż takie rozumienie kultury jest punktem wyjścia do stworzenia trwałego oraz otwartego systemu współpracy między różnorodnymi podmiotami działalności kulturalnej (jednostkami samorządu terytorialnego, in- 
stytucjami kultury, placówkami edukacji i nauki, organizacjami pozarządowymi, grupami nieformalnymi, mieszkańcami). Jednym z najważniejszych celów programu „Dzielnice Kultury” jest usuwanie barier i trudności w dostępie do kultury. Wśród najważniejszych czynników utrudniających mieszkańcom dostęp do kultury organizatorzy wskazali bariery przestrzenne, czasowe i finansowe. Ich likwidacji mają służyć m.in. takie działania, jak: wzmocnienie oferty instytucji kultury funkcjonujących w dzielnicach; tworzenie nowych punktów umożliwiających kontakt z kulturą; poszerzenie dotychczasowej współpracy podmiotów w zakresie działalności kulturalnej; poszukiwanie nowych miejsc, w których można realizować działania kulturalno-edukacyjne; dostosowanie do potrzeb mieszkańców godzin pracy instytucji kultury; wsparcie finansowe oferty kulturalnej; tworzenie systemów zniżek; rozwój prorodzinnej oferty kulturalnej.

Kluczowym etapem w procesie tworzenia programu była diagnoza infrastruktury kulturalno-edukacyjnej lubelskich dzielnic, w efekcie której zostało wyodrębnionych pięć ich typów. W pierwszej grupie znalazły się dzielnice centralne, w obrębie których znajduje się największa liczba podmiotów prowadzących działalność kulturalną i edukacyjną. W ich obszarze nie odnotowano znaczących barier o charakterze komunikacyjnym. Grupę drugą stanowią dzielnice zlokalizowane w pewnej odległości od centrum, charakteryzujące się dość dobrym stopniem komunikacji z pozostałymi dzielnicami oraz względnie dobrze rozwiniętą bazą instytucjonalną. Do grupy trzeciej zakwalifikowano nowe dzielnice peryferyjne, głównie z jednorodzinną zabudową. Cechuje je słabo rozwinięta sieć komunikacyjna i brak infrastruktury kulturalno-edukacyjnej. Czwarta grupa obejmuje tzw. obszary poprzemysłowe, w obrębie których znajduje się bardzo skromna ilość instytucji kultury. W dużej mierze są to obszary zagrożone wykluczeniem społecznym. Ostatnia grupa to dzielnice o charakterze wiejsko-miejskim, z niesatysfakcjonującą infrastrukturą edukacyjno-kulturalną.

Koordynatorem programu „Dzielnice Kultury” jest Wydział Kultury Urzędu Miasta Lublin. Finansowanie działań odbywa się dwutorowo: w ramach otwartego konkursu ofert i naboru projektów w trybie pozakonkursowym na podstawie art. 19a ustawy o działalności pożytku publicznego i wolontariacie oraz w ramach wsparcia realizacji projektów przez dzielnicowych operatorów programu, czyli trzy miejskie instytucje kultury: Dzielnicowy Dom Kultury „Bronowice”, Dzielnicowy Dom Kultury „Węglin” oraz Warsztaty Kultury. Każda z tych instytucji koordynuje działania w dziewięciu dzielnicach miasta, z uwzględnieniem specyfiki i potrzeb danego obszaru.

Od początku istnienia programu do końca $2017 \mathrm{r}$. zostały zrealizowane w sumie 824 projekty. Łączna kwota ich finansowego wsparcia wyniosła 6501784 zł. Zdecydowaną większość projektów (507) stanowiły działania o charakterze warsztatowym. Pozostałe projekty miały charakter: spotkań/wykładów (129), festynów dzielnicowych/imprez plenerowych (96), koncertów (77), pokazów/wy- 
staw/spektakli (55). Największą grupę projektów (364) stanowiły działania adresowane przede wszystkim do dzieci. Adresatami 296 projektów były wszystkie grupy wiekowe. W przypadku 168 projektów podstawową grupę odbiorców stanowiła młodzież. Nieco mniej (147 projektów) to działania adresowane głównie do osób dorosłych. Seniorzy stanowili natomiast podstawową grupę odbiorców w przypadku 87 projektów.

W trakcie pięciu edycji programu w dzielnicach w szczególnym stopniu dotkniętych wykluczeniem społeczno-kulturalnym nastąpiła znaczna poprawa infrastruktury kulturalnej. Powstały w tym czasie dwie filie dzielnicowych domów kultury oraz trzy filie Miejskiej Biblioteki Publicznej, z powodzeniem realizujące funkcje lokalnych ośrodków kultury. Najważniejszym efektem programu są jednak liczne projekty o charakterze animacyjnym, szczególnie te zrealizowane w dzielnicach w największym stopniu zagrożonych wykluczeniem. W dzielnicach peryferyjnych, zakwalifikowanych na etapie diagnozy do grupy trzeciej, zostały dotychczas zrealizowane 234 projekty. W dzielnicach poprzemysłowych, które zaliczono do czwartej grupy, zorganizowano łącznie 117 projektów, a w dzielnicach o charakterze wiejsko-miejskim, które stanowiły przesłankę do wyodrębnienia piątego typu dzielnic, liczba zrealizowanych projektów wyniosła 203.

Prezentowane tu dane ilościowe nie obrazują oczywiście realnego zasięgu programu. Nierzadko bowiem aktywność kulturalna mieszkańców wychodzi poza określoną przestrzeń, a społeczność lokalna gromadzi się wokół projektów również w innych, często odległych miejscach. Fakt ten podkreślają także uczestnicy projektu badawczego „Kultura w dzielnicach 2017”, zrealizowanego w celu ewaluacji dotychczasowych działań, pogłębienia wiedzy na temat potencjałów i potrzeb poszczególnych dzielnic oraz wskazania ewentualnych obszarów optymalizacji programu. Jedna z badanych stwierdziła: „....) ludzie, którzy tu się widują, zaczynają się spotykać na różnych wydarzeniach kulturalnych w innych miejscach. (...) Także ta kultura tu zaszczepiona skutkuje. Jak się spotka bliżej kogoś tu, to inspiruje do samodzielnego rozwijania swoich umiejętności. I wtedy łatwiej pójść za tym dalej, szukać". Badani podkreślali również wzrastającą świadomość mieszkańców na temat programu, przejawiającą się z jednej strony $\mathrm{w}$ coraz większym zainteresowaniu uczestnictwem w konkretnych projektach, z drugiej zaś chęcią samodzielnego projektowania działań: „(...) dla mnie bardzo ważne jest to, że jeżeli dajemy inicjatywę mieszkańcom, to ludzie zaczynają się otwierać na te możliwości, przyglądają się. Coraz więcej osób włącza się do tego programu i to największa wartość tego projektu. To, że jest to dla mieszkańców”. Fakt, iż program adresowany jest właśnie do mieszkańców, stanowi - zdaniem badanych - największą jego wartość, umożliwia bowiem zaspokajanie autentycznych potrzeb społeczności lokalnych: ,....) bardzo dobre jest to, że mogą mieszkańcy i grupy niezależne realizować działania, bo jednak większość programów adresowanych jest do podmiotów posiadających osobowość prawną. To ważne, 
bo wtedy jest bliska relacja - w większym stopniu projekt można dostosować do potrzeb mieszkańców, skoro znamy specyfikę". Wśród innych atutów programu mieszkańcy dzielnic wskazują także: faktyczny rozwój lokalnej oferty kulturalnej; wyrównywanie szans uczestnictwa w kulturze; wzmocnienie integracji mieszkańców; przystępny dla wszystkich sposób aplikowania o fundusze.

\section{ZAKOŃCZENIE}

Wzrastająca świadomość społeczna na temat znaczenia działalności kulturalnej sprawia, że kultura przestaje być ujmowana wyłącznie jako wartość autoteliczna. Jej rola ujawnia się w sferze społecznej aktywizacji i partycypacji, co jest fundamentem budowania kapitału społecznego. Wśród metod współczesnej działalności kulturalnej, sprzyjających wzmacnianiu lokalnej aktywności, szczególne miejsce należy przypisać animacji społeczno-kulturalnej. Zaprezentowane w niniejszym opracowaniu inkluzywne przesłanki animacji pozwalają traktować ją jako atrakcyjną i efektywną metodę przeciwdziałania wykluczeniu społecznemu, umożliwiającą likwidowanie barier w dostępie do kultury oraz tworzenie warunków do realizacji autentycznych potrzeb kulturalnych. Uwypuklenie roli animacji społeczno-kulturalnej w procesach szeroko pojmowanej inkluzji z pewnością przyczynia się do intensyfikacji działań praktycznych w tym obszarze, które - jak pokazuje zaprezentowany w niniejszym opracowaniu program „Dzielnice Kultury" - doskonale realizują zadanie likwidowania czasowych, przestrzennych, psychologicznych oraz komunikacyjnych barier w dostępie do kultury, jak również rozwijania współpracy będącej elementarnym czynnikiem partycypacji społecznej i kulturalnej.

Niewielkie zainteresowanie badaczy tym wycinkiem rzeczywistości poznawczej, przekładające się na skromny wachlarz opracowań naukowych, rodzi postulat zrealizowania zaawansowanych badań, których efekty doprowadzą do bardziej wnikliwego spojrzenia na problematykę wykluczenia społecznego, uwzględniającą obok spopularyzowanych już kategorii (biedni - bogaci, pełnosprawni - niepełnosprawni, bezrobotni - pracujący), również dychotomię ,uczestniczący nieuczestniczący w kulturze".

\section{BIBLIOGRAFIA}

Bell D. (1994), Kulturowe sprzeczności kapitalizmu, Warszawa: Wydawnictwo Naukowe PWN.

Bendyk E. (2013), Pętle wykluczenia i nieobecności, [w:[ E. Rokicka, P. Kruczkowska (red.), Oblicza ekskluzji. Praktyka działania instytucji kultury a przełamywanie barier, Łódź: Ministerstwo Kultury i Dziedzictwa Narodowego.

Friske K.W. (1999), Marginalność społeczna, [w:] Encyklopedia socjologii, t. 2, Warszawa: Oficyna Naukowa.

Giddens A. (2004), Socjologia, Warszawa: Wydawnictwo Naukowe PWN. 
Grad J., Kaczmarek U. (2005), Organizacja i upowszechnianie kultury w Polsce. Zmiany modelu, Poznań: Wydawnictwo Naukowe UAM.

Idzikowski B. (2013), Teoria i praktyka animacji kultury w czasach ponowoczesnych, [w:] D. Kubinowski, U. Lewartowicz (red.), Animacja kultury. Wspótczesne dyskursy teorii i praktyki, Lublin: MAKmed.

Kłosowski W. (2011a), Kultura na rzecz zmiany społecznej, [w:] W. Kłosowski (red.), Kierunek kultura. W stronę żywego uczestnictwa w kulturze, Warszawa: Mazowieckie Centrum Kultury i Sztuki.

Kłosowski W. (2011b), Od redaktora, [w:] W. Kłosowski (red.), Kierunek kultura. W stronę żywego uczestnictwa w kulturze, Warszawa: Mazowieckie Centrum Kultury i Sztuki.

Kubinowski D. (2013), Współczesne paradygmaty animacji kultury, [w:] D. Kubinowski, U. Lewartowicz (red.), Animacja kultury. Wspótczesne dyskursy teorii i praktyki, Lublin: MAKmed.

Kukołowicz T. (2016), Geograficzna dostępność kultury a wykluczenie z uczestnictwa w kulturze instytucjonalnej, „Kultura Współczesna”, nr 1.

Lewicki T. (1993), Fenomen animacji. O praktyce i teoriach działalności społecznej, kulturalnej $i$ wychowawczej we Włoszech, „Problemy Opiekuńczo-Wychowawcze”, nr 4.

Mahler F. (1993), Marginality and Maldevelopment, [w:] J. Danecki (red.), Insights into Maldevelopment, Warszawa: Uniwersytet Warszawski.

Mendel M. (2004), Animacja wspótpracy środowiskowej, [w:] M. Mendel (red.), Animacja wspótpracy środowiskowej, Toruń: Wydawnictwo Adam Marszałek.

Nalaskowski F. (2007), Ubóstwo a wykluczenie z kultury jako problem dla edukacji, Olsztyn: Wydawnictwo Uczelniane Wyższej Szkoły Informatyki i Ekonomii TWP.

Rokicka E. (2013), Lokalne instytucje kultury a wykluczenie z uczestnictwa w kulturze, [w:] E. Rokicka, P. Kruczkowska (red.), Oblicza ekskluzji. Praktyka działania instytucji kultury a przełamywanie barier, Łódź: Ministerstwo Kultury i Dziedzictwa Narodowego.

Rokicka E., Kruczkowska P. (red.) (2013), Oblicza ekskluzji. Praktyka działania instytucji kultury a przełamywanie barier, Łódź: Ministerstwo Kultury i Dziedzictwa Narodowego.

Szarfenberg R. (2010), Marginalizacja i wykluczenie społeczne - panorama językowo-teoretyczna, [w:] R. Szarfenberg, C. Żołędowski, M. Theiss (red.), Ubóstwo i wykluczenie - perspektywa poznawcza, Warszawa: Dom Wydawniczy Elipsa.

\section{SUMMARY}

The aim of this article is characterizing social and cultural animation as a way of counteracting exclusion from the culture. The starting point of suggested considerations is the wide understanding of the culture - not only as an autotelic value but more importantly as a tool of social participation and one of the fundaments of building the social capital. The key features of animation in the perspective of social and cultural inclusion have been presented in the study. The most crucial models and paradigms have been characterized emphasizing the threads connected to the issue of social and cultural exclusion. An animated programme "Culture districts" has been presented, and was a perfect example of the issues that have been discussed. The programme has been successfully run by the city of Lublin since 2013. Its main aim is removing spacial, organizational and financial barriers in the access to culture, and integration and social and cultural mobilization of the residents.

Keywords: social and cultural animation; exclusion from the culture; social exclusion; social and cultural inclusion 